\title{
Seagull influence on soil properties, chenopod shrub distribution, and leaf nutrient status in semi-arid Mediterranean islands
}

Luis V. García, Teodoro Marañón, Fernando Ojeda, Luis Clemente and Ramón Redondo

García, L. V., Marañón, T., Ojeda, F., Clemente L. and Redondo, R. 2002. Seagull
influence on soil properties, chenopod shrub distribution, and leaf nutrient status in semi-arid Mediterranean islands. - Oikos 98: 75-86.

\begin{abstract}
Concentration of seagulls in the Chafarinas Islands (three semi-arid North African islets) induces profound changes in soil properties including eutrophication, salinization, acidification and nutrient imbalances. Soils of heavily seabird-affected sites have significantly higher soluble $\mathrm{K}$ and $\mathrm{NO}_{3}$ levels ( $>20$-fold), $\mathrm{Zn}$ and $\mathrm{Fe}$ availability ( $>5$-fold), water-retention capacity ( $>40 \%$ increase) and ${ }^{15} \mathrm{~N}$ enrichment, compared with control sites. These seabird-induced soil changes are paralleled by (i) different patterns of abundance of the two main chenopod shrubs: Suaeda vera abundance is higher ( $>30$-fold) in seabird-affected sites while Salsola oppositifolia largely dominates in low-affected areas. No differences were found for Atriplex halimus. The abundance of the first two species may be largely explained by changes in soil soluble $\mathrm{K}$-to-available $\mathrm{Ca}$ ratio whose value depends of the interaction between seabird products and soil constituents; (ii) significant increases in leaf N, P and $\mathrm{Zn}$ levels, and in all $\mathrm{K}$ ratios, paralelled by a decrease in $\mathrm{Ca}$, in Salsola; but only by increased $\mathrm{K} / \mathrm{Na}$ and $\mathrm{P} / \mathrm{Ca}$ ratios in Suaeda leaves. These changes were significantly correlated to changes in species abundances; (iii) an increase of $\delta^{15} \mathrm{~N}$, paralleled by a decrease in $\delta^{13} \mathrm{C}$ values, in Salsola leaves but not in Suaeda.

Conjoint analysis of the seabird-related changes in soil properties, species abundance, leaf composition and differential response to the seabird-induced fertilization/severity gradient of the two main chenopod shrub species, has led us to propose an explanatory hypothesis of seagull-soil-shrub relationships. According to this, the seagull-induced soil changes, mediated by processes of (in)tolerance-facilitation, play a main role in determining the abundance and the leaf nutrient status of the studied chenopod shrubs, which have contrasting physiological adaptations.
\end{abstract}

L.V. García(ventura@cica.es),T. Marañón and L. Clemente, IRNA, CSIC, P.O. Box 1052, E-41080 Sevilla, Spain. - F. Ojeda, Depto. de Biología Vegetal y Ecología, Univ. Sevilla, Spain. Present address: Dpto. de Biología, CASEM, Universidad de Cádiz, Pol. Río San Pedro s/n, E-11510 Puerto Real, Spain. - R. Redondo, Facultad de Ciencias, Univ. Autónoma de Madrid, E-28049 Madrid, Spain.

The accumulation of seabird guano often alters the chemical composition of soils and may change the performance of plants and the competitive interactions between them, favouring nutrient-demanding species (Gillham 1956, Sobey and Kenworthy 1979, Hogg and Morton 1983, Vidal et al. 2000). Soil around seabird colonies tends to be enriched with $\mathrm{N}$ and $\mathrm{P}$, soluble salts, and organic matter (Smith 1978, 1979), while pH may either increase (Gillham 1960, Bukacinski et al. 1994) or decrease (Hogg and Morton 1983). Recent evidences have shown the role of seabirds as main vectors moving heavy metals (either essential micronutrients or purely toxic) to Arctic peat soils (Headley 1996) or to soils of eastern-Atlantic Islands, where seagulls have proliferated during the last few decades (Otero 1998).

The worldwide demographic explosion of some seagull species (due to higher island protection and increased food availability) has increased interest in effects of seabirds on soils and plants (Vidal et al. 1998,

Accepted 17 October 2001

Copyright (C) OIKOS 2002

ISSN 0030-1299 
2000). In arid environments, where seabird-induced influence on soils is expected to have deeper and more persistent effects (Hutchinson 1950, Gillham 1961), there is a lack of detailed data on seagull-soil-plant relations.

Previous studies on seabird affected sites have found a significant $\mathrm{N}$ and $\mathrm{P}$ enrichment in plants from arid (Anderson and Polis 1999) and from sub-Antarctic islands (Smith 1978), and some micronutrient enrichment has been reported for a grass species from the maritime Antarctic, along a gradient of penguin influence (Tatur et al. 1997), but no data exist on shrub enrichment in heavy-metal micronutrients, or on differential responses in the composition of shrub species related to seagull influences.

In this paper we aim to answer the following questions: 1) do seabird products increase soil fertility, acidity, and salinity levels in semi-arid Mediterranean islands? 2) do seagull products affect other soil parameters such as heavy-metal micronutrient bio-availability, water retention capacity, and specific fractions or ratios between relevant nutrients? 3) do seagull products affect the concentration of macro- and micronutrient in shrub leaves? 4) can seagull-induced changes in soil properties explain the differential distribution of the dominant chenopod shrub species?

\section{Methods}

\section{Study site}

The Chafarinas Islands are located at the south-western end of the Mediterranean Sea, four miles off the Moroccan coast. They are three volcanic semiarid $(320 \mathrm{~mm}$ mean annual rainfall) islets. Two of the islands, Congreso (22 ha) and Rey (13 ha), support nesting colonies of the Audouin's gull (Larus audouinii Payr.), a rare and protected Mediterranean seabird, and of the widespread yellow-legged gull (L. cachinnans Pallas), a Mediterranean seabird "pest". Seagull populations in 2001 were ca 2700 pairs in Congreso, and ca 4200 in Rey. In 1976 the figures were 600 and 1200 pairs, respectively. The third island (Isabel, 15 ha) is inhabited and has had negligible seabird influence since 1848 .

The vegetation of the islets is sparse and dominated by the chenopod shrubs Salsola oppositifolia Desf., Suaeda vera Forsskal and, to a lesser extent, Atriplex halimus L. For simplicity we will hereafter refer to the species by their genus name.

\section{Plant and soil analyses}

Shrub cover was measured in 26 transects of $50 \mathrm{~m}$ line randomly distributed among the vegetated areas of the islands. In each transect a bulked soil sample (collected from three random points) was taken.
Soil samples were air-dried, crushed and sieved $(<2$ $\mathrm{mm})$. Available (or extractable) calcium $\left(\mathrm{Ca}_{\mathrm{a}}\right)$, magnesium $\left(\mathrm{Mg}_{\mathrm{a}}\right)$ and potassium $\left(\mathrm{K}_{\mathrm{a}}\right)$ were extracted using neutral $1 \mathrm{M}$ ammonium acetate; electrical conductivity $\left(\mathrm{EC}_{\mathrm{s}}\right)$ and soluble ions $\left(\mathrm{Na}_{\mathrm{s}}, \mathrm{K}_{\mathrm{s}}, \mathrm{Ca}_{\mathrm{s}}, \mathrm{Mg}_{\mathrm{s}}, \mathrm{Cl}_{\mathrm{s}}, \mathrm{NO}_{3 \mathrm{~s}}\right.$ and $\mathrm{SO}_{4 \mathrm{~s}}$ ) were measured in soil saturation extracts. $\mathrm{Na}^{+}$and $\mathrm{K}^{+}$were measured by flame photometry, $\mathrm{Ca}^{2+}$ and $\mathrm{Mg}^{2+}$ by atomic absorption spectroscopy, $\mathrm{Cl}^{-}$by titration with $\mathrm{AgNO}_{3}$, and $\mathrm{NO}_{3}^{-}$and $\mathrm{SO}_{4}^{2-}$ by visible spectrophotometry. Saturation percentage (SP) was measured as the gravimetric water content of the soil saturate paste. Soil total inorganic carbonates (TIC) were measured using a pressure-calcimeter. Organic carbon (OC) was determined using a modified Walkley and Black method, and total organic nitrogen (N) using a Kjeldahl digestion and distillation-titration of the produced ammonium. Available phosphorus $\left(\mathrm{P}_{\mathrm{a}}\right)$ was extracted using sodium bicarbonate $(0.5 \mathrm{M}, \mathrm{pH}$ 8.5 ), and measured by visible spectrophotometry using ammonium molybdate and ascorbic acid. The availability of four heavy-metal micronutrients ( $\mathrm{Fe}, \mathrm{Cu}, \mathrm{Mn}$ and $\mathrm{Zn}$ ) was determined using an ICP-OES device, after extraction with a neutral 0.05 M-EDTA solution. $\mathrm{pH}$ and electrical conductivity were measured electrometrically in 1:1 soil paste and saturation extracts, respectively. Soil particle size was measured using a Boyoucos hydrometer. Activities of selected ions and osmotic potentials in soil saturation extracts were computed according to Bressler et al. (1982) and Rieu et al. (1998).

For each chenopod species, terminal shoots $(10 \mathrm{~cm})$ of three randomly selected individual plants were taken at each sampling transect, and mixed to make one single sample for chemical analysis. In total, we analyzed 48 samples from 144 individuals ( 57 of Salsola, 54 of Suaeda, and 33 of Atriplex). They were rinsed, oven-dried, ground, calcinated $\left(500^{\circ} \mathrm{C}\right)$, dissolved and filtered. Extracted plant mineral elements were determined using an ICP-OES device. $\mathrm{N}$ was measured by Kjeldahl digestion.

The same leaf material used for plant nutrient analysis was used for $\mathrm{C}$ and $\mathrm{N}$ isotope determinations, using an EA-IRMS in continuous flow. The precision for both $\delta^{13} \mathrm{C}$ and $\delta^{15} \mathrm{~N}$ analyses was \pm 0.2 per mil. Soil $\delta^{15} \mathrm{~N}$ values at different levels of the seabird-influence gradient were measured in bulked, air-dried, soil samples in the same way as for plant leaves.

High $\delta^{15} \mathrm{~N}$ values are expected in soils receiving seabird products because of the ${ }^{15} \mathrm{~N}$ enrichment along the marine food chains, and the isotopic fractionation occurring during volatilization of the ammonia from seabird products (Mizutani and Wada 1988, Stapp et al. 1999). This seabird signal is also detected in plants that have taken up seabird-derived N-compounds (Cocks et al. 1998, Anderson and Polis 1998, 1999, Stapp et al. 1999). High $\delta^{13} \mathrm{C}$ values are expected in $\mathrm{C}_{4}$ plants $\left(-15\right.$ to $-9 \%$ ) with respect to $C_{3}$ plants $\left(\delta^{13} \mathrm{C}\right.$ 
from -32 to $-22 \%$ ), mainly because of differences in the discrimination against the heavier isotope in the initial carboxylation (Winter 1981, Akhani et al. 1997, Stapp et al. 1999)

\section{Numerical analyses}

Sampling sites were classified according to the seabird influence (SEABIRD variable) on the following $(0-3)$ scale: (0): Sites that have been free from any direct seabird influence for decades (the case of Isabel Island). The distance to active seagull colonies is usually $>500$ $\mathrm{m}$ : (1) sites relatively far $(80-500 \mathrm{~m})$ from the areas documented as dense nesting or roosting places and with no evidence of seagull activities on the soil surface; (2) sites with evidence of recent seabird activities on the soil surface (drops, feathers, etc.), but that have not been mapped as places of permanent, dense nesting colonies; (3) sites mapped as supporting dense nesting colonies during most years and having evident signs of seagull activities on the soil surface.

Significant differences between the levels of seabird influence affecting soil and plant variables, and variable association, were tested using parametric (Student $t$, ANOVA, Pearson r), or alternative non-parametric (bootstrap, Bruce et al. 1999) tests when the required assumptions were not satisfied, even after transformations. To avoid the inflation of "familywise" type I error rate, we have applied the sequential-Bonferroni correction (Holm 1979) where repeated tests were carried out.

Multivariate structure of environmental (23 soil parameters) and leaf composition (10 variables) data was explored applying principal component analysis (PCA), after confirming the domination of linear relationships between these variables. A stepwise canonical correspondence analysis (CCA) was performed to find the optimal combination of soil variables (if any) that

Table 1. Correlation coefficients between variables related to the intensity of the seabird activities (SEABIRD and soil $\mathrm{OC} / \mathrm{N}$ ratio) and soil properties: first soil-PCA axis scores, macro- (N, P and K) and micronutrient $(\mathrm{Zn})$, salinity (EC), and water-retention capacity (SP). Only correlation coefficients with $p<0.005$ are shown $(p<0.001$, in bold).

\begin{tabular}{|c|c|c|}
\hline \multirow[t]{2}{*}{ Soil property } & \multicolumn{2}{|c|}{ Seabird indicator variable } \\
\hline & SEABIRD & $\mathrm{OC} / \mathrm{N}$ \\
\hline PCA Axis 1 & 0.85 & -0.70 \\
\hline $\mathrm{K}_{\mathrm{S}}$ & 0.89 & -0.71 \\
\hline $\mathrm{NO}_{3}$ & 0.85 & -0.58 \\
\hline$P_{a}$ & 0.77 & - \\
\hline EC & 0.74 & -0.70 \\
\hline $\mathrm{N}$ & 0.65 & -0.55 \\
\hline SP & 0.63 & -0.61 \\
\hline $\mathrm{PH}$ & -0.58 & 0.56 \\
\hline $\mathrm{Zn}$ & 0.56 & - \\
\hline $\mathrm{Fe}$ & 0.56 & - \\
\hline
\end{tabular}

significantly explained the species relative abundance data. Species overlap was calculated according Slobodchikoff and Schulz (1980).

\section{Results}

\section{Soil gradients and seabird influence}

The first axis of the PCA analysis explained almost half $(47 \%)$ of the total variance in soil data. It was significant $(p<0.005)$ and positively correlated to available $\mathrm{P}$, to overall salinity (EC), to soluble ions (mainly to $\mathrm{K}_{\mathrm{s}}$, $\mathrm{NO}_{3 \mathrm{~s}}$ and $\mathrm{Mg}_{\mathrm{s}}$ ), to organic-matter-related variables (OC and $\mathrm{N}$ ), to availability of some micronutrients ( $\mathrm{Zn}$ and $\mathrm{Fe}$ ) and to soil water retention capacity (SP), but negatively correlated to $\mathrm{pH}$ and to available $\mathrm{Ca}$.

The estimated intensity of seabird influence (variable SEABIRD) was significantly and positively correlated $(p<0.005)$ to scores of the first axis of soil PCA and to some other soil variables (Table 1$)$. The $\mathrm{OC} / \mathrm{N}$ ratio, which has been documented by Moors et al. (1988) as a surrogate of true indicators (as $\delta^{15} \mathrm{~N}$ ), was negatively correlated $(p<0.005)$ to SEABIRD variable and to scores of PCA axis 1 (Table 1).

Soil $\delta^{15} \mathrm{~N}$ values were lower in "seabird-free" areas (range 10.5-13.4\%o) than in highly-influenced ones $(16.8-20.8 \%$ ) , thus confirming the seabird-effect gradient. $\delta^{15} \mathrm{~N}$ values of soil samples, bulked for each level of seabird influence $(0-3)$, were $11.5,15.3,17.9$ and $19.0 \%$, respectively, which support the proposed scale of seabird influence. Average SEABIRD values per-island $(0.0,1.6$ and 2.5$)$, adequately reproduced the measured inter-island gradients of seagull density (none, 114 and 262 nesting pairs/ha, during the 199397 period, respectively) and soil $\delta^{15} \mathrm{~N}$ values $(11.5,16.0$ and $19.1 \%$, respectively).

\section{Seabird influence on soil properties}

A comparison of average values for the 20 soil variables potentially affected by seabird influence is shown in Table 2. Only one of the highly correlated $(r>0.90)$ groups of variables (i.e. EC- $\mathrm{Cl}_{\mathrm{s}}-\mathrm{SO}_{4 \mathrm{~s}}-\mathrm{Na}_{\mathrm{s}}, \mathrm{N}-\mathrm{OC}$, ClaySand, $\mathrm{K}_{\mathrm{s}}-\mathrm{K}_{\mathrm{s}} / \mathrm{Ca}_{\mathrm{a}}$ ) has been tested.

The expected soil enrichment in macronutrients and organic matter (organic- $\mathrm{N}$, nitrate, $\mathrm{P}$ and $\mathrm{K}$ ), as well as in salinity (EC), at sites with increased seagull influence, is confirmed (Table 2). All these variables were markedly (at least two-fold) higher in areas supporting intense seagull activities.

Additional soil changes have been found: 1) water-retention capacity (SP) increased greatly $(45 \%)$ in seagullaffected soils. These differences cannot be attributed to differences in the mineral substrate or in particle size; 2) there was a substantial increase in the soil soluble 
Table 2. Differences in 20 soil properties between areas with different degree of seabird influence. Mean \pm SE (only for extreme levels), $F$-values significance $\left(* p<0.05, * * p<0.01\right.$ and $\left.{ }^{* * *} p<0.001\right)$ for individual one-way ANOVA (4 seabird levels, $\mathrm{df}=22$ ), and $p$-values for one-tailed t-tests $(\mathrm{df}=16)$, are shown. For clarity, original (non-transformed) values are shown. Comparisons seen to be significant after applying sequential-Bonferroni correction are marked in bold.

\begin{tabular}{|c|c|c|c|c|c|}
\hline \multirow[t]{2}{*}{ Soil variable } & \multirow[t]{2}{*}{ Symbol } & \multicolumn{2}{|c|}{ Seabird influence } & \multirow{2}{*}{$\frac{\text { ANOVA }}{F(p)}$} & \multirow{2}{*}{$\frac{\text { One-tailed t-tests }}{\left(\mathrm{H}_{1}: \mu_{\text {high }}>\mu_{\text {low }}\right)(p)}$} \\
\hline & & Control & High & & \\
\hline Saturation percentage (\%) & SP & $38.9 \pm 0.8$ & $56.3 \pm 4.0$ & $5.32 * *$ & 0.000 \\
\hline Kjedhal nitrogen $(\%)$ & $\mathrm{N}$ & $0.15 \pm 0.01$ & $0.42 \pm 0.09$ & $5.85^{* *}$ & 0.000 \\
\hline Available P $(\mathrm{mg} / \mathrm{kg})$ & $P_{a}$ & $50.0 \pm 4.2$ & $217 \pm 39.1$ & $10.8^{* *}$ & 0.000 \\
\hline Available $\mathrm{K}(\mathrm{mg} / \mathrm{kg})$ & $\mathrm{K}_{\mathrm{a}}$ & $359 \pm 51$ & $1151 \pm 114$ & $5.83^{* *}$ & 0.005 \\
\hline Available $\mathrm{Mg}(\mathrm{mg} / \mathrm{kg})$ & $\mathrm{Mg}_{\mathrm{a}}$ & $498 \pm 8$ & $692 \pm 95$ & 1.14 & 0.061 \\
\hline Available Ca (mg/kg) & $\mathrm{Ca}_{\mathrm{a}}$ & $4569 \pm 84$ & $3762 \pm 230$ & 1.60 & 0.015 \\
\hline Electrical Conductivity $(\mathrm{dS} / \mathrm{m})$ & $\mathrm{EC}$ & $1.8 \pm 0.3$ & $9.9 \pm 1.0$ & $9.73^{* * *}$ & 0.000 \\
\hline Soluble $\mathrm{K}(\mathrm{mg} / \mathrm{kg})$ & $\mathrm{K}_{\mathrm{s}}$ & $8.8 \pm 2.1$ & $190 \pm 36.2$ & $36.5^{* * *}$ & 0.000 \\
\hline Soluble $\mathrm{Mg}(\mathrm{mg} / \mathrm{kg})$ & $\mathrm{Mg}_{\mathrm{s}}$ & $15.1 \pm 6.0$ & $133 \pm 38.3$ & $10.8^{* * *}$ & 0.000 \\
\hline Soluble $\mathrm{Ca}(\mathrm{mg} / \mathrm{kg})$ & $\mathrm{Ca}_{\mathrm{s}}$ & $51.0 \pm 19.1$ & $312 \pm 91.9$ & $5.65^{* *}$ & 0.003 \\
\hline Soluble $\mathrm{NO}_{3}(\mathrm{mg} / \mathrm{kg})$ & $\mathrm{NO}_{3 \mathrm{~s}}$ & $69.5 \pm 21.2$ & $1915 \pm 392$ & $31.8^{* * *}$ & 0.000 \\
\hline Available $\mathrm{Cu}(\mathrm{mg} / \mathrm{kg})$ & $\mathrm{CU}$ & $2.4 \pm 0.3$ & $6.5 \pm 1.9$ & 0.680 & 0.052 \\
\hline Available Fe (mg/kg) & $\mathrm{Fe}$ & $7.2 \pm 1.7$ & $38.1 \pm 12.3$ & $4.06^{*}$ & 0.002 \\
\hline Available Mn (mg/kg) & $\mathrm{Mn}$ & $20.5 \pm 4.1$ & $77.0 \pm 24.2$ & 2.96 & 0.027 \\
\hline Available $\mathrm{Zn}(\mathrm{mg} / \mathrm{kg})$ & $\mathrm{Zn}$ & $6.1 \pm 0.8$ & $36.2 \pm 9.1$ & $3.32 *$ & 0.002 \\
\hline $\mathrm{PH}$ & $\mathrm{pH}$ & $7.4 \pm 0.03$ & $6.8 \pm 0.17$ & $5.12 *$ & 0.000 \\
\hline Quotient $\mathrm{OC}$ to $\mathrm{N}$ & $\mathrm{OC} / \mathrm{N}$ & $9.6 \pm 0.5$ & $7.3 \pm 0.3$ & $5.66^{* *}$ & 0.000 \\
\hline Quotient $\mathrm{Ca}_{\mathrm{a}}$ to $\mathrm{P}_{\mathrm{a}}$ & $\mathrm{Ca}_{\mathrm{a}} / \mathrm{P}_{\mathrm{a}}$ & $92.9 \pm 9.6$ & $22.7 \pm 4.6$ & $9.92^{* * *}$ & 0.000 \\
\hline Total inorganic carbonates $(\%)$ & TIC & $18.5 \pm 5.0$ & $9.1 \pm 2.0$ & 2.12 & 0.350 \\
\hline Clay $(\%)$ & Clay & $25.2 \pm 2.1$ & $22.6 \pm 3.1$ & 0.26 & 0.220 \\
\hline
\end{tabular}

fraction of $\mathrm{K}$ (average $22 \times$ of control) and to a lower extent of soluble $\mathrm{Mg}$ and $\mathrm{Ca}$ (up to $9 \times$ ), in highly seagull-influenced sites, but patterns of the corresponding available fractions were less marked; 3) the ratio soluble $\mathrm{K} /$ available $\mathrm{K}$ and the ratios between soil extractable $\mathrm{Ca}$ and some seabird-influenced elements (such as $\mathrm{K}_{\mathrm{s}}$ or $\mathrm{P}_{\mathrm{a}}$ ) were also strongly affected; 4) the bio-availability of the heavy metals $\mathrm{Zn}$ and $\mathrm{Fe}$ was significantly higher (5-fold) in seabird-influenced soils, while the increase (4-fold) in Mn was only marginally significant (Table 2).

We have thus found significant differences in soil features, other than soil macronutrient fertilization or salinization, associated to seabird activities.

\section{Abundance of chenopod shrubs}

The three chenopod species showed different patterns of abundance at different levels of seagull influence (Fig. 1). Salsola had its average relative cover reduced 30 -fold in the habitat highly affected by seabirds (bootstrapped-ANOVA $p<0.001$ ), while Suaeda had the highest average abundance there (bootstrappedANOVA $p<0.001)$. The ecological overlap between the two main species was low (alpha index $=0.04$ ). No significant differences were found in Atriplex (bootstrapped ANOVA $p=0.68$, Fig. 1).

These differences between species were also shown by the significant correlations with the SEABIRD variable: negative for Salsola $(r=-0.65, p<0.001)$, positive for Suaeda $(r=+0.63, p<0.001)$, and non-significant for Atriplex.
After performing a stepwise CCA analysis, a very highly significant model ( $p<0.001$ after a Monte Carlo test) of two canonical axes was obtained, accounting for some $50 \%$ of total species relative abundance variance. From a total of 25 independent variables, only the ratios $\mathrm{K}_{\mathrm{s}} / \mathrm{Ca}_{\mathrm{a}}$ and $\mathrm{OC} / \mathrm{N}$ were retained as the best explanatory set of environmental variables (Table 3 ).

\section{Changes in leaf chemical composition and seabird influence}

The leaves of Salsola from highly seagull-affected sites had significantly higher $\mathrm{P}, \mathrm{Zn}, \mathrm{N}$ and $\mathrm{K}$, but lower $\mathrm{Ca}$

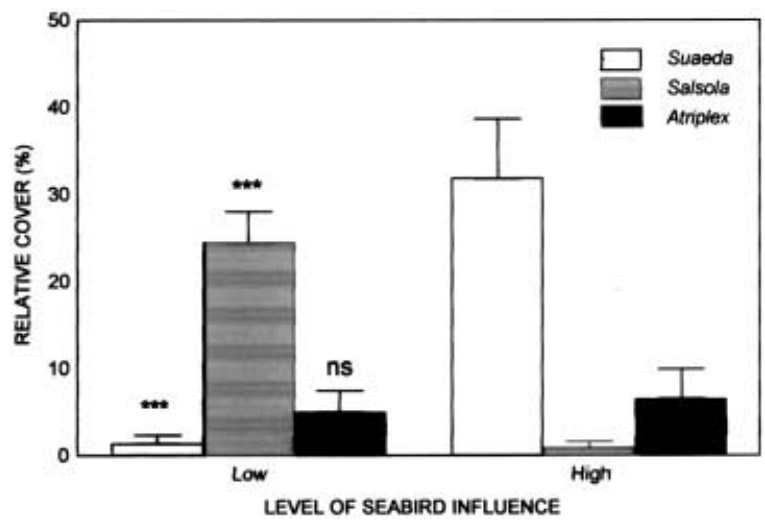

Fig. 1. Abundance (relative cover) of three chenopod shrub species - Salsola oppositifolia, Suaeda vera and Atriplex halimus - in sites having low and high levels of seabird influence. Mean, S.E. half-bar, and bootstrapped significance of the mean differences are shown $(* * * p<0.001$, ns: $p=0.68)$. 
Table 3. Summary of the species-environment relationship analysis. (a) Results of stepwise direct gradient analysis (CCA), including relevant parameters of the two axes which are significant after applying Monte Carlo test $(p<0.0001)$ Eigenvalues, percentage of explained variance, percentage of fitted variance for each species, and species-environment correlations. (b) Correlations between environmental CCA-axis scores and (i) the main trend of variation in soil data (PCA axis 1); (ii) environmental CCA-explanatory soil variables $\left(\mathrm{K}_{\mathrm{s}} / \mathrm{Ca}_{\mathrm{a}}, \mathrm{OC} / \mathrm{N}\right)$ and estimated (SEABIRD) or surrogate $(\mathrm{OC}$ $\mathrm{N}$ ) indicators of soil seabird influence; and (iii) single variables related to different soil aspects (macro- and micronutrient levels, salinity, water retention, and acidity) that significantly correlated to some CCA axis. Only correlations with $p<0.005$ are shown $(p<0.001$, in bold $)$.

\begin{tabular}{|c|c|c|}
\hline & CCA axis 1 & $\mathrm{CCA}$ axis 2 \\
\hline \multicolumn{3}{|l|}{ (a) Direct gradient analysis } \\
\hline Eigenvalues & 0.53 & 0.11 \\
\hline Explained variance $(\%)$ & 40.9 & 8.6 \\
\hline \multicolumn{3}{|l|}{ Species fitted variance $(\%)$} \\
\hline Suaeda & 45.5 & 6.5 \\
\hline Salsola & 62.4 & 0.4 \\
\hline Atriplex & 5.2 & 23.5 \\
\hline $\begin{array}{l}\text { Species-environment } \\
\text { correlations }\end{array}$ & 0.79 & 0.50 \\
\hline \multicolumn{3}{|c|}{ (b) Correlations of environmental-CCA axes to: } \\
\hline $\begin{array}{l}\text { (i) main soil trend (PCA } \\
\text { axis 1) }\end{array}$ & -0.93 & - \\
\hline \multicolumn{3}{|c|}{ (ii) canonical explanatory and seabird indicators } \\
\hline $\mathrm{K}_{\mathrm{s}} / \mathrm{Ca}_{\mathrm{a}}$ & -1.00 & - \\
\hline $\mathrm{OC} / \mathrm{N}^{\mathrm{a}}$ & 0.72 & 0.69 \\
\hline SEABIRD & -0.87 & - \\
\hline \multicolumn{3}{|c|}{ (iii) potentially seabird-related soil variables } \\
\hline $\mathrm{K}_{\mathrm{s}}$ & -0.97 & - \\
\hline $\mathrm{NO}_{3}$ & -0.84 & - \\
\hline $\mathrm{EC}$ & -0.81 & - \\
\hline $\mathrm{P}_{\mathrm{a}}$ & -0.78 & - \\
\hline $\mathrm{Zn}$ & -0.75 & - \\
\hline $\mathrm{Fe}$ & -0.65 & - \\
\hline SP & -0.64 & - \\
\hline $\mathrm{PH}$ & 0.66 & - \\
\hline $\mathrm{Ca}_{\mathrm{a}}$ & 0.54 & - \\
\hline
\end{tabular}

than plants from control sites (Table 4). Fe and Mn levels were also increased ( $>2$-fold) but the high data variability gave a non-significant result. Similarly, the ratios relating $\mathrm{K}$ to $\mathrm{Ca}$ and $\mathrm{Mg}$ in leaves significantly increased, while $\mathrm{Ca} / \mathrm{Zn}$ and $\mathrm{Ca} / \mathrm{P}$ decreased, at sites highly-affected by seagulls (Table 4). The composition of Suaeda leaves was much less affected by seagulls: higher $\mathrm{K} / \mathrm{Na}$ and lower $\mathrm{Ca} / \mathrm{P}$ ratios were the most remarkable changes in the heavily affected sites. The leaves of Atriplex did not show any significant changes (Table 4).

A comparison between the three species showed that Salsola was richer in $\mathrm{Ca}$ and $\mathrm{Mg}$ than Suaeda. But Atriplex and Suaeda accumulated more $\mathrm{Na}$ than Salsola. (Table 4).

In coexisting plants, the average (relative) concentration of the measured minerals in Salsola was higher (37-99\%) than in Suaeda leaves at all levels of seabird influence. On the other hand, the relative increase in nutrient concentration along the seabird fertilization gradient averaged $89 \%$ in Salsola against $10 \%$ in Suaeda leaves. If only key nutrients - those whose soil availability is most probably affected by seabird products (N, P, K, Fe, Zn, Mn) - are considered, the figures rise to an average of $157 \%$ in Salsola leaves, against $23 \%$ in Suaeda.

The average isotopic composition of Salsola leaves changed significantly with seabird influence, whereas no significant changes were found for Suaeda values (Table 5). The main independent trend in Salsola leaf composition (first PCA axis, Fig. 2A) was significantly correlated to the intensity of seabird influence (SEABIRD variable), and to the main detected environmental gradients (Table 6). Therefore, a statistically significant link between the increased seabird influence, the increased soil fertilization-salinization, and the leaf-increased (or decreased) contents of some essential macro- and micronutrients can be established for Salsola in the Chafarinas Islands. This main trend in Salsola leaves was mostly explained (near $70 \%$ of variance) by the changes of soil variables (as $\mathrm{K}_{\mathrm{s}}$ and $\mathrm{Mn}$ ), which may be related to seagull activities. This pattern is strongly supported by the observed relationships between Salsola $\delta^{15} \mathrm{~N}$ values and the other soil, leaf, and seabird-influence variables (Table 7). These results relate changes in a seabird signal (Salsola $\delta^{15} \mathrm{~N}$ values) to changes in key soil variables $\left(\mathrm{K}_{\mathrm{s}}, \mathrm{NO}_{3}\right.$, salinity, $\mathrm{pH}$, and $\mathrm{Mn}$ ), to leaf components (, $\mathrm{P}$ and $\mathrm{Zn}$ ), and to the SEABIRD variable. Noticeably, the highest (in absolute value) correlation of Salsola $\delta^{15} \mathrm{~N}$ values ( $r=$ $-0.77, p<0.0002$ ) was to the main explanatory gradient of species distribution (CCA axis 1, Table 7).

In the case of Suaeda, the main trend in leaf composition (PCA axis 1, Fig. 2B), despite being associated to leaf $\mathrm{P}, \mathrm{Ca}, \mathrm{Mg}, \mathrm{Zn}, \mathrm{Mn}$ and $\mathrm{Cu}$ concentration, was not directly related to the SEABIRD variable, or to any of the main environmental gradients (Table 6). However, the second trend (PCA axis 2) in leaf composition, associated to a drop in $\mathrm{Na}$ and a rise in $\mathrm{N}, \mathrm{K}$ and $\mathrm{Fe}$ levels (Fig. 2B, Table 6), was significantly related to seabird influence (SEABIRD variable). Three soil variables $\left(\mathrm{K}_{\mathrm{s}}, \mathrm{Mn}\right.$ and $\left.\mathrm{Zn}\right)$ explained $75 \%$ of the variance in this 2nd leaf trend. No significant relationship existed between Suaeda $\delta^{15} \mathrm{~N}$ values and seabird-related soil/ leaf variables (Table 7).

Atriplex leaf composition had little relationship with soil variables (Table 6). Therefore, we have found distinct species responses to the seabird-induced soil changes: there was a full response in Salsola leaf macronutrients, $\mathrm{Zn}$, and many nutrient ratios; a lower response (related to $\mathrm{K}-\mathrm{Na}$ exchanges and to a $\mathrm{Ca} / \mathrm{P}$ decrease) in Suaeda; and a null response in Atriplex leaves (Table 4). These differential patterns of response are further confirmed by: 1) higher number, significance and explanatory power of the soil-leaf variables rela- 
tionships in Salsola (Table 6 and 8); and 2) the significant leaf $\delta^{15} \mathrm{~N}$ changes along the seabird gradient (Table 5), and the multiple significant relationships between leaf $\delta^{15} \mathrm{~N}$ and other leaf and soil variables in Salsola, but not in Suaeda (Table 7).

On the other hand, Salsola $\delta^{13} \mathrm{C}$ was negatively related to the SEABIRD variable, and to soil $\left(\mathrm{K}_{\mathrm{s}}\right.$ and $\mathrm{NO}_{3}$ ) and leaf ( $\mathrm{N}$ and $\mathrm{Fe}$ ) variables that positively correlated to seabird influence (Table 7), including Salsola $\delta^{15} \mathrm{~N}(r=-0.76$, bootstrapped $p<0.001)$, and the main detected environmental (Soil PCA axis 1, Environmental CCA axis 1) and leaf composition gradients (Leaf PCA axis 1). In contrast, soil $\mathrm{Na}_{\mathrm{s}}, \mathrm{Mg}_{\mathrm{s}}$, and the 2nd tendency in leaf composition (Table 6, Fig. 2A) were all positively related to Salsola $\delta^{13} \mathrm{C}$ values. No seabird-related variable was associated to Suaeda $\delta^{13} \mathrm{C}$ values (Table 7 ).

\section{Leaf composition and shrub abundance}

There were two leaf variables with a highly significant monotonic relationship to Salsola abundance: Ca con- centration (explaining about $60 \%$, bootstrapped $p<$ 0.001 , of its relative cover variance), and $\mathrm{Zn}$ concentration, which was negatively correlated to Salsola abundance $(r=-0.65$, bootstrapped $p=0.001)$. These leaf predictors of plant abundance were, in turn, closely related to soil variables significantly changed by seagull presence (Table 8).

In the case of Suaeda, the $\mathrm{Ca} / \mathrm{P}$ ratio in leaves accounted for over $45 \%$ of its relative cover variance; and the combination of leaf $\mathrm{Ca} / \mathrm{P}$ ratio with leaf $\mathrm{Na}$ concentration (negatively) explained about $65 \%$ of the species cover. These two leaf variables were negatively correlated to soil nutrient concentration: $\mathrm{Ca} / \mathrm{P}$ ratio in leaves to soil $\mathrm{P}_{\mathrm{a}}(r=-0.69, p<0.005)$, and $\mathrm{Na}$ in leaves to soil $\mathrm{K}_{\mathrm{s}}(r=-0.60, p<0.01)$. Changes in other leaf variables (such as $\delta^{15} \mathrm{~N}, \delta^{13} \mathrm{C}$, and PCA axis1 in Salsola) are also related to the distribution of the two main chenopods, because of their high correlation to environmental CCA axis 1, which -in turn- explains a highly significant proportion of species relative abundance variance, including their absence, through the unimodal approach (Table 3, 6 and 7).

Table 4. Influence of seagull presence on leaf nutrient concentration of the three chenopod species. Mean \pm 1 SE of each element at the two ends of the seabird-influence gradient ("Low" and "High"), ANOVA $F$-value (4 seabird levels), and level of significance for each individual comparison are indicated $(* p<0.05, * * p<0.01$ and $* * * p<0.001)$. $F$-values that were significant after the sequential-Bonferroni correction are in bold.

\begin{tabular}{|c|c|c|c|c|c|c|c|c|c|}
\hline \multirow[t]{2}{*}{ Leaf variable } & \multicolumn{2}{|c|}{ Salsola oppositifolia } & \multirow[b]{2}{*}{$\begin{array}{l}F \\
(\mathrm{df}=15)\end{array}$} & \multicolumn{2}{|l|}{ Suaeda vera } & \multirow[b]{2}{*}{$\begin{array}{l}F \\
(\mathrm{df}=15)\end{array}$} & \multicolumn{2}{|c|}{ Atriplex halimus } & \multirow[b]{2}{*}{$\begin{array}{l}F \\
(\mathrm{df}=8)\end{array}$} \\
\hline & Low & High & & Low & High & & Low & High & \\
\hline $\mathrm{N}(\%)$ & $2.00 \pm 0.19$ & $3.87 \pm 0.21$ & $14.5 * * *$ & $3.09 \pm 0.19$ & $3.54 \pm 0.13$ & 2.55 & $2.39 \pm 0.08$ & $2.75 \pm 0.12$ & 1.64 \\
\hline P $(\%)$ & $0.09 \pm 0.00$ & $0.36 \pm 0.07$ & $7.72 * *$ & $0.14 \pm 0.01$ & $0.19 \pm 0.02$ & 3.54 & $0.28 \pm 0.04$ & $0.27 \pm 0.01$ & 0.04 \\
\hline K (\%) & $1.92 \pm 0.29$ & $3.38 \pm 0.47$ & $3.99 *$ & $1.60 \pm 0.11$ & $2.13 \pm 0.18$ & $3.69 *$ & $2.09 \pm 0.13$ & $2.32 \pm 0.21$ & 0.33 \\
\hline $\mathrm{Ca}(\%)$ & $2.21 \pm 0.14$ & $1.29 \pm 0.07$ & $5.03 *$ & $0.52 \pm 0.07$ & $0.49 \pm 0.04$ & 2.94 & $1.66 \pm 0.17$ & $1.21 \pm 0.10$ & 1.64 \\
\hline $\operatorname{Mg}(\%)$ & $0.83 \pm 0.02$ & $0.70 \pm 0.04$ & 1.60 & $0.42 \pm 0.03$ & $0.41 \pm 0.01$ & 1.78 & $1.53 \pm 0.12$ & $1.36 \pm 0.03$ & 0.24 \\
\hline $\mathrm{Na}(\%)$ & $5.92 \pm 0.70$ & $5.22 \pm 0.47$ & 0.84 & $10.9 \pm 1.14$ & $8.35 \pm 0.40$ & $5.07 *$ & $11.3 \pm 0.33$ & $11.0 \pm 0.60$ & 0.31 \\
\hline $\mathrm{Cu}(\mathrm{mg} / \mathrm{kg})$ & $6.33 \pm 1.86$ & $7.25 \pm 2.10$ & 0.64 & $8.80 \pm 1.36$ & $8.13 \pm 1.17$ & 0.19 & $10.5 \pm 2.02$ & $7.20 \pm 1.16$ & 0.92 \\
\hline $\mathrm{Fe}(\mathrm{mg} / \mathrm{kg})$ & $142 \pm 2.2$ & $319 \pm 51.0$ & 1.99 & $182 \pm 14.3$ & $239 \pm 37.9$ & 1.26 & $206 \pm 35.4$ & $169 \pm 8.28$ & 0.10 \\
\hline $\mathrm{Mn}(\mathrm{mg} / \mathrm{kg})$ & $40.0 \pm 10.4$ & $94.5 \pm 34.4$ & 1.26 & $46.8 \pm 7.92$ & $62.5 \pm 12.4$ & 1.44 & $84.3 \pm 16.5$ & $45.4 \pm 12.7$ & 0.19 \\
\hline $\mathrm{Zn}(\mathrm{mg} / \mathrm{kg})$ & $15.0 \pm 0.58$ & $46.8 \pm 4.77$ & $16.2 * * *$ & $22.2 \pm 6.44$ & $19.6 \pm 2.7$ & 0.03 & $63.8 \pm 12.4$ & $42.2 \pm 6.2$ & 0.97 \\
\hline $\mathrm{K} / \mathrm{Na}$ & $0.33 \pm 0.07$ & $0.68 \pm 0.16$ & $3.74^{*}$ & $0.15 \pm 0.02$ & $0.26 \pm 0.03$ & $8.74 * *$ & $0.18 \pm 0.01$ & $0.22 \pm 0.03$ & 0.72 \\
\hline $\mathrm{K} / \mathrm{Ca}$ & $0.87 \pm 0.12$ & $2.68 \pm 0.48$ & $8.47 * *$ & $3.32 \pm 0.53$ & $4.40 \pm 0.29$ & 3.10 & $1.28 \pm 0.09$ & $1.93 \pm 0.11$ & 4.18 \\
\hline $\mathrm{K} / \mathrm{Mg}$ & $2.31 \pm 0.34$ & $4.88 \pm 0.72$ & $8.74 * *$ & $3.93 \pm 0.44$ & $5.22 \pm 0.43$ & 1.99 & $1.38 \pm 0.08$ & $1.70 \pm 0.14$ & 0.75 \\
\hline $\mathrm{Ca} / \mathrm{Zn}$ & $1476 \pm 121$ & $289 \pm 47.3$ & $14.6^{* * *}$ & $279 \pm 47.1$ & $270 \pm 30.5$ & 0.92 & $309 \pm 86.1$ & $325 \pm 73.5$ & 2.05 \\
\hline $\mathrm{Ca} / \mathrm{P}$ & $25.5 \pm 0.90$ & $4.27 \pm 1.10$ & $17.6^{* * *}$ & $3.72 \pm 0.38$ & $2.69 \pm 0.28$ & $4.54^{*}$ & $6.78 \pm 1.88$ & $4.59 \pm 0.47$ & 0.83 \\
\hline
\end{tabular}

Table 5. Relative abundance of stable isotopes of $\mathrm{N}$ and $\mathrm{C}$ in leaves of the two dominant chenopod shrubs, at the two extreme levels of seabird influence. Mean $\pm 1 \mathrm{SE}$, sample sizes, $F$-values and significance levels of mean homogeneity tests (bootstrapped $p$ for Salsola $\delta^{13} \mathrm{C}$ values, and parametric ANOVA $p$ 's for the remaining variables) are shown.

\begin{tabular}{crrrrr}
\hline & \multicolumn{2}{l}{ Seabird influence } & & \\
\cline { 2 - 5 } & \multicolumn{1}{l}{ Low } & High & $\mathrm{n}$ & \multicolumn{1}{l}{ F } & $p$ \\
\hline Salsola & $9.8 \pm 1.2$ & $17.4 \pm 0.6$ & 16 & 14.5 & 0.0003 \\
$\delta^{15} \mathrm{~N}(\%)$ & $-11.7 \pm 0.1$ & $-14.2 \pm 0.3$ & 16 & - & $<0.001$ \\
$\delta^{13} \mathrm{C}(\%)$ & & & & 0.1 & 0.92 \\
Suaeda & $16.6 \pm 0.9$ & $16.9 \pm 0.5$ & 16 & 1.1 & 0.38 \\
$\delta^{15} \mathrm{~N}(\%)$ & $-23.3 \pm 1.0$ & $-24.5 \pm 0.3$ & 13 & & \\
$\delta^{13} \mathrm{C}(\%)$ & & & & \\
\hline
\end{tabular}



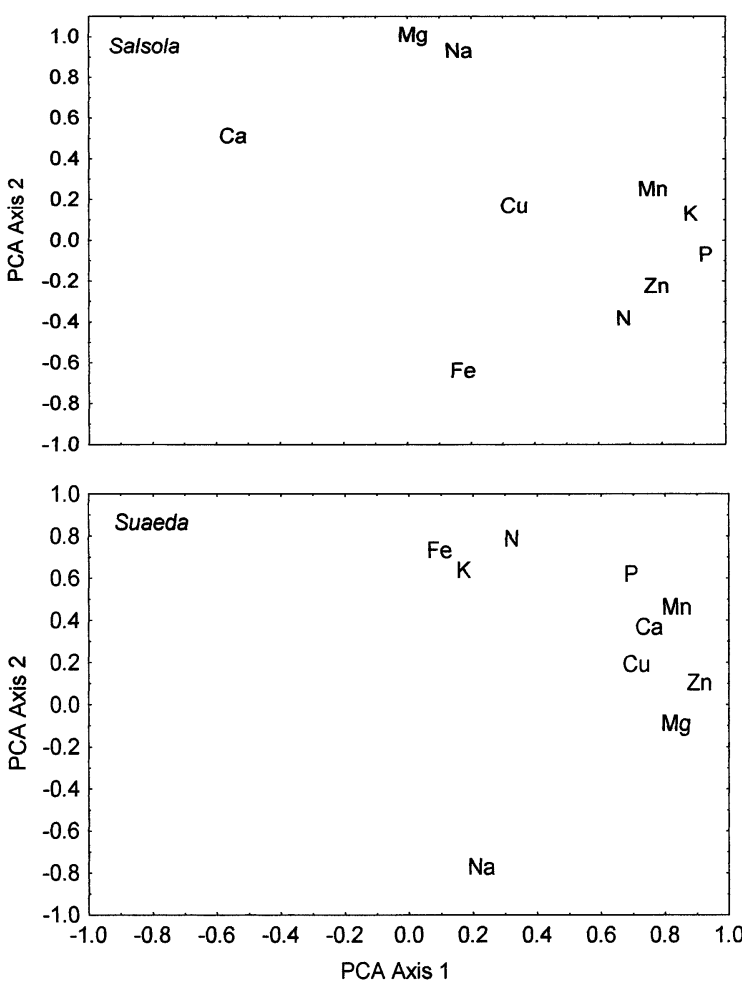

Fig. 2. PCA factor loadings for the ten mineral elements measured in leaves of Salsola oppositifolia (upper graph) and of Suaeda vera (lower graph). In both species the two first PCA axes explained about $40 \%$ and $25 \%$ of the total variance, respectively.

\section{Discussion}

\section{Seabird-induced soil changes}

In the Chafarinas Islands, seabirds play a major role in driving many soil properties which may influence plant establishment, nutritional status and survival. The significant correlations found between the seabird-influence variables (SEABIRD, OC/N) and the main tendency of variation in 23 measured soil physical and chemical properties, as well as the significant differences existing between different seabird-influence levels for many relevant soil properties, and for soil $\delta^{15} \mathrm{~N}$ values, strongly support this conclusion.

It is remarkable that the $\delta^{15} \mathrm{~N}$ values of the seabirdfree soils $(10.5-13.4 \%$ ) are higher than those reported elsewhere for other "control" sites (Mizutani and Wada 1988, Cocks et al. 1998, Hawke et al. 1999) and even than those found by us (L. V. García and T. Marañón, unpubl.) in truly seabird-free mainland soils under $\mathrm{Sal}$ sola $(5.6-7.6 \%)$. Seabird-derived products may remain in soils for decades (Mizutani et al. 1991, Hawke et al. 1999), and thus a possible pre-settlement soil enrichment by seagull influence in the current seabird-free soils should be borne in mind. In particular, long-term effects can be produced for low mobile elements such as $P$ and heavy metals, which may remain immobilized in this type of arid and calcareous soils for hundreds of years (Anderson and Polis 1999, Hawke et al. 1999).

In fact, present "seabird-free" soils in the Chafarinas Islands have apparently enough absolute availability of most nutrients (according to reference levels in Wild

Table 6. Relationships between the main tendencies (PCA axes) of variation in the leaf composition, analyzed separately for the three chenopod species, with the single soil and leaf components, the main environmental gradients (Soil PCA and CCA axes) and the estimated intensity of seabird influence (SEABIRD). Sets of soil variables that best explained the leaf-compositional axes have been selected by stepwise linear regression. A minus sign $(-)$ indicates that the variable is negatively correlated/contributing to the leaf PCA component. Variable association is tested by Pearson parametric or non-parametric (bootstrap) tests. Significance level for individual correlations has been set at $p<0.005$ to avoid Type I error inflation in the whole test set $\left(-p>=0.005,{ }^{*} p<0.005\right.$ and $\left.* * p<0.001\right)$.

\begin{tabular}{|c|c|c|c|c|c|c|}
\hline & \multicolumn{2}{|c|}{ Salsola oppositifolia } & \multicolumn{2}{|l|}{ Suaeda vera } & \multicolumn{2}{|l|}{ Atriplex halimus } \\
\hline & PCA axis 1 & PCA axis 2 & PCA axis 1 & PCA axis 2 & PCA axis 1 & PCA axis 2 \\
\hline \multicolumn{7}{|l|}{ Leaf components } \\
\hline $\begin{array}{l}\text { Correlations } \\
\quad(p<0.005)\end{array}$ & $\begin{array}{l}\mathrm{P}, \mathrm{K}, \mathrm{Zn}, \\
\mathrm{Mn}, \mathrm{N}\end{array}$ & $\mathrm{Mg}, \mathrm{Na}, \mathrm{Fe}(-)$ & $\begin{array}{l}\mathrm{P}, \mathrm{Zn}, \mathrm{Mn} \\
\mathrm{Mg}, \mathrm{Ca}, \mathrm{Cu}\end{array}$ & $\mathrm{N}, \mathrm{Fe}, \mathrm{Na}(-)$ & $\begin{array}{l}\mathrm{Ca}, \mathrm{Mg}, \mathrm{Fe}, \\
\mathrm{N}(-)\end{array}$ & $\mathrm{Zn}, \mathrm{P}$ \\
\hline \multicolumn{7}{|l|}{ Soil variables } \\
\hline $\begin{array}{r}\text { Correlations } \\
(p<0.005)\end{array}$ & $\begin{array}{l}\mathrm{K}_{\mathrm{s}}, \mathrm{NO}_{3 \mathrm{~s}} \\
\mathrm{Mn}, \mathrm{EC} \\
\mathrm{Mg}\end{array}$ & - & $\mathrm{TIC}(-)$ & $\mathrm{K}_{\mathrm{s}}$ & $\mathrm{Na}_{\mathrm{s}}(-), \mathrm{Cl}_{\mathrm{s}}(-)$ & - \\
\hline Best explanatory set & $\mathrm{K}_{\mathrm{s}}, \mathrm{Mn}$ & $\begin{array}{l}\mathrm{K}_{\mathrm{s}}(-), \mathrm{Na}_{\mathrm{s}}, \\
\mathrm{OC} / \mathrm{N}\end{array}$ & $\mathrm{Mn}, \mathrm{EC}, \mathrm{pH}$ & $\mathrm{K}_{\mathrm{s}}, \mathrm{Zn}(-), \mathrm{Mn}$ & $\mathrm{Na}_{\mathrm{s}}(-)$ & - \\
\hline Multiple-R & $0.82 * *$ & $0.81 * *$ & $0.82 * *$ & $0.87 * *$ & $0.79 *$ & - \\
\hline \multicolumn{7}{|l|}{ Environmental gradients } \\
\hline Soil PCA axis 1 & $0.77 * *$ & - & - & - & - & - \\
\hline Env. CCA axis 1 & $-0.78 * *$ & - & - & - & - & - \\
\hline SEABIRD & $0.68^{*}$ & - & - & $0.70^{*}$ & - & - \\
\hline
\end{tabular}


Table 7. Relationships between the isotopic composition $\left(\delta^{15} \mathrm{~N}\right.$ and $\left.\delta^{13} \mathrm{C}\right)$ of Salsola and Suaeda leaves with other single leaf-composition, single environmental variables and gradients (Soil PCA and CCA axes), and the intensity of seabird influence (SEABIRD). Sets of soil and leaf variables that best explained the delta-variables were selected by stepwise linear regression. A minus sign (-) indicates that the variable is negatively correlated/contributing to the isotope enrichment. Variable association is tested by Pearson parametric or non-parametric (bootstrap) tests. Significance level for individual correlations has been set at $p<0.005$ to avoid Type I error inflation in the whole test set $\left(-p>=0.005,{ }^{*} p<0.005\right.$ and $\left.{ }^{* *} p<0.001\right)$.

\begin{tabular}{|c|c|c|c|c|}
\hline & \multicolumn{2}{|c|}{ Salsola oppositifolia } & \multicolumn{2}{|c|}{ Suaeda vera } \\
\hline & $\delta^{15} \mathrm{~N}$ & $\delta^{13} \mathrm{C}$ & $\delta^{15} \mathrm{~N}$ & $\delta^{13} \mathrm{C}$ \\
\hline \multicolumn{5}{|l|}{ Leaf variables } \\
\hline Correlations $(p<0.005)$ & $\mathrm{N}, \mathrm{P}, \mathrm{Zn}$ & $\mathrm{N}(-), \mathrm{Fe}(-)$ & - & - \\
\hline Best explanatory set & N, P & $\mathrm{N}(-)$ & - & - \\
\hline Multiple-R & $0.90^{* *}$ & $0.81 * *$ & - & - \\
\hline Leaf PCA axis 1 & $0.80^{* *}$ & - & & \\
\hline axis 2 & - & $0.79 *$ & - & - \\
\hline \multicolumn{5}{|l|}{ Soil variables } \\
\hline Correlations $(p<0.005)$ & $\mathrm{K}_{\mathrm{s}}, \mathrm{NO}_{3 \mathrm{~s}}, \mathrm{EC}$ & $\mathrm{NO}_{3 \mathrm{~s}}(-), \mathrm{K}_{\mathrm{s}}(-)$ & - & - \\
\hline Best explanatory set & $\mathrm{K}_{\mathrm{s}}, \mathrm{Mn}, \mathrm{pH}$ & $\mathrm{NO}_{3 \mathrm{~s}}(-), \mathrm{Na}_{\mathrm{s},} \mathrm{Mg}_{\mathrm{s}}$ & - & - \\
\hline Multiple-R & $0.90^{* *}$ & $0.91 * *$ & - & - \\
\hline Soil PCA axis 1 & $0.71 *$ & - & - & - \\
\hline Env. CCA axis 1 & $-0.77 * *$ & $-0.66^{*}$ & - & - \\
\hline SEABIRD & $0.74^{*}$ & $-0.73^{*}$ & - & - \\
\hline
\end{tabular}

Table 8. Correlation between the seabird-influence variable, and several soil variables and ratios, with selected single leaf compositional variables, which significantly changed across the seabird influence gradient. Variable association is tested by Pearson parametric or non-parametric (bootstrap) tests. Only correlation coefficients having $p<0.005$ are shown $(p<0.001$ in bold).

\begin{tabular}{|c|c|c|c|c|c|c|}
\hline \multirow[t]{2}{*}{ Leaf variables } & \multicolumn{6}{|c|}{ Environmental variables } \\
\hline & SEABIRD & Soil PCA 1 & $\mathrm{~K}_{\mathrm{s}} / \mathrm{Ca}_{\mathrm{a}}$ & $\mathrm{Ca}_{\mathrm{a}} / \mathrm{P}_{\mathrm{a}}$ & EC & $\mathrm{Zn}$ \\
\hline \multicolumn{7}{|l|}{ Salsola } \\
\hline $\mathrm{N}$ & 0.74 & - & 0.65 & - & - & - \\
\hline $\mathrm{P}$ & 0.74 & 0.85 & 0.84 & -0.74 & 0.76 & - \\
\hline $\mathrm{K}$ & - & 0.75 & 0.69 & - & 0.63 & - \\
\hline $\mathrm{Ca}$ & -0.66 & -0.64 & -0.65 & 0.65 & - & -0.79 \\
\hline $\mathrm{Zn}$ & 0.79 & 0.85 & 0.91 & -0.76 & 0.69 & 0.75 \\
\hline $\mathrm{K} / \mathrm{Ca}$ & 0.74 & 0.85 & 0.81 & -0.74 & - & 0.78 \\
\hline $\mathrm{Ca} / \mathrm{Zn}$ & -0.87 & -0.83 & -0.87 & 0.77 & - & -0.82 \\
\hline $\mathrm{Ca} / \mathrm{P}$ & -0.82 & -0.88 & -0.89 & 0.77 & -0.71 & -0.71 \\
\hline \multicolumn{7}{|l|}{ Suaeda } \\
\hline $\mathrm{K} / \mathrm{Na}$ & 0.75 & - & 0.67 & - & - & - \\
\hline $\mathrm{Ca} / \mathrm{P}$ & - & - & - & 0.69 & - & - \\
\hline
\end{tabular}

1988) to allow plant development. However, their levels of $\mathrm{Mn}(15-28 \mathrm{ppm})$ and $\mathrm{Fe}(4-9 \mathrm{ppm})$ are below acceptable minima (50 and $10 \mathrm{ppm}$, respectively, Martens and Lindsay 1990).

Soils having a "high seabird influence" all had excessive contents of extractable $\mathrm{P}, \mathrm{K}$ and $\mathrm{Mg}$ (compared with levels of reference in Wild 1988), and of soluble salts. Thus, adverse effects for plant growth and nutrient imbalances are expected. Furthermore, we have determined that half of the studied heavily seabird-affected sites exceed the established Zn-phytotoxicity threshold $(300 \mathrm{mg} / \mathrm{Kg}$ of acid-extractable $\mathrm{Zn}$, in $\mathrm{Ka}-$ bata-Pendias and Pendias 1992). Therefore, the seabird influence has apparently transformed the soil conditions in Chafarinas Islands: soluble $\mathrm{K}$ and $\mathrm{NO}_{3}$ have increased $>20$-fold, and available $\mathrm{P}, \mathrm{K}, \mathrm{Fe}, \mathrm{Zn}$, salinity, $\mathrm{N}$ and $\mathrm{OC}$ (from 1.4 to $3 \%$ ) contents $>2-8$ fold, compared with control soils.
Most of the studies reporting seabird effects on soil properties have focused mainly on changes in organic and inorganic $\mathrm{N}$ and $\mathrm{P}$ levels, while seabird-induced changes in soil extractable or soluble $\mathrm{K}$ have received less attention (Smith 1978, 1979, Sobey and Kenworthy 1979, Hogg and Morton 1983, Vidal et al. 1998, 2000). Nevertheless, it has been demonstrated for several seabird species (including seagulls, Burger et al. 1978) that $\mathrm{K}$ contents of seabird faeces may be higher (up to 3-fold) than their P contents.

Soluble potassium increased strongly in the seabirdaffected soils of the Chafarinas Islands; in these soils the soluble $\mathrm{K}$ fraction represents an average of nearly $20 \%$ (with a maximum of $45 \%$ ) of the total available $\mathrm{K}$, whereas in seabird-free soils this fraction was much lower (about 2.5\%) as commonly found in "normal" soils (Marschner 1995). This strong enrichment in soil soluble $\mathrm{K}$ is mostly from seagull products, rather than 
Table 9. Comparison between ratios of some soluble constituents $(\mathrm{Cl}, \mathrm{Na}$ and $\mathrm{K})$ in seawater, saturation extracts of Chafarinas Islands soils (non- and heavily influenced by seagulls), and seagull faeces. Ratios have been calculated on a weight basis. Data on adult and chick (in brackets) seagull faeces have been derived from Sobey and Kenworthy (1979), while data from seawater is taken from Malloch (1972).

\begin{tabular}{lccll}
\hline & Seawater & Soil, no seabird & Soil, high seabird & Herring gull faeces \\
\hline $\mathrm{Cl} / \mathrm{Na}$ & 1.8 & 1.6 & 1.4 & - \\
$\mathrm{Na} / \mathrm{K}$ & 27.5 & 11.9 & 4.4 & $4.9(0.2)$ \\
\hline
\end{tabular}

marine spray as was suggested by Smith (1978) for sub-Antarctic islands. The main supporting pieces of evidence are 1) the highly significant $(r>0.80, p<$ $0.001)$ positive correlation to several seabird-indicators, such as SEABIRD, soil and Salsola leaf $\delta^{15} \mathrm{~N}$ levels and soil nitrate, 2) the strong enrichment in soluble $\mathrm{K}$ of soils along the seabird-influence gradient, with respect to other typical sea-spray constituents $(\mathrm{Cl}$ and $\mathrm{Na})$, and 3) the $\mathrm{Na} / \mathrm{K}$ values in fouled sites, which are close to those found in adult seagull faeces (Table 9).

Nutrient ratios have been overlooked in other studies of seagull-induced effects on soils and plant communities. In sites with seagull colonies of the Chafarinas Islands, the ratio $\mathrm{Ca}_{\mathrm{s}} / \mathrm{K}_{\mathrm{s}}$ had unusually low values (about 2, on a $\mathrm{mol} / \mathrm{mol}$ basis), compared with control soils (near 8) and with most soils (average of 10, Mengel and Kirkby 1982). An enrichment in soluble K, in relation to soluble fractions of $\mathrm{Ca}, \mathrm{Mg}$, and even $\mathrm{Na}$, as well as in $\mathrm{NO}_{3}$ relative to $\mathrm{Cl}$, seems to be typical of seabird-affected soils under dry climates with respect to the general saline condition.

\section{Plant responses to soil changes}

The general ecological and evolutionary scenario for plants living in the semi-arid Chafarinas Islands includes an intrinsically low availability of most nutrients, caused by the low water availability and a low availability of some essential nutrients (as P and heavymetal micronutrients) which have a reduced solubility in alkaline, calcium-rich soil environments (Marschner 1995, Ström 1997). Plants thriving in such conditions tend to exhibit adaptations such as the exudation of low-molecular-weight organic acids (Ström 1997), a succulent morphology, a sodium-increased water efficiency, and $\mathrm{C}_{4}$ metabolic pathways (Marschner 1995).

Seabird activity has significantly affected critical soil parameters with expected consequences for plant growth. Several soil changes can be highlighted:

1) Increased water and nutrient retention. The seagull-induced increase of soil organic matter originates, in turn, an increase in the soil capacity for water retention (some 40-45\%), and thus enhances the fertilization effect (Mengel and Kirkby 1982). This affects the moisture regime of Chafarinas aridic and shallow soils, and may favour the establishment of plants less tolerant to the prevailing harsh dry conditions.
2) Soil acidification and increased $P$ and micronutrient availability. The mineralization of the seabird-added organic matter and the subsequent nitrification, significantly decrease the soil $\mathrm{pH}$ (up to 2 units) in the heavily seabird-affected topsoils. Chelating agents (resulting from organic matter decomposition) further increase heavy-metal availability in calcareous and manured Aridisols (Srivastava and Sethi 1981). Such increases in the availability of critical nutrients must influence the performance of perennials plants suited to cope with a shortage of some nutrients, which have to switch to tolerate an excess of them.

3) Increased salinity and unbalanced soil solutions. The higher salinity of soils affected by seabirds has important consequences for the soil water potential, but also in the "effective ratio" of nutrients to be taken up by plants (Table 10). As the ionic strength of the soil solution increases, there is a faster lowering of activity coefficients of divalent versus monovalent cations (Bressler et al. 1982). For example, the average $\mathrm{Ca} / \mathrm{K}$ value for seabird-affected soils is 1.9 when calculated from analytical concentrations, but much lower (0.6) when calculated applying iterative speciation models (Rieu et al. 1998). Therefore, "real" seabird-induced nutrient imbalances in soils are more severe than those predicted from analytical concentrations.

Apparently, there is an ecological filter of plants able to live in semi-arid seagull-affected soils: they must tolerate extremely imbalanced soil solutions and low osmotic potentials. Nevertheless, plants which are able to overcome these harsh conditions may benefit from the increased soil water-retention capacity and from the higher macro- and micronutrient availability.

Table 10. Seabird influence on the ratio of a divalent- to a monovalent-ion nutrient $\left(\mathrm{Ca}^{++} / \mathrm{K}^{+}\right)$. Ratios of analytical concentrations, ion activities, and osmotic potential of soil saturation extracts, from three sites free of seabird influence ("Control") and from three sites having a high level of seabird influence ("High") are shown.

\begin{tabular}{llll}
\hline $\begin{array}{l}\text { Seabird } \\
\text { influence }\end{array}$ & $\mathrm{Ca}^{++} / \mathrm{K}^{+}$ & $\begin{array}{l}\text { Osmotic pot. } \\
(\mathrm{kPa})\end{array}$ \\
\cline { 2 - 3 } & Analytical & Activity & \\
\hline Control & 7.77 & 3.88 & -66 \\
High & 1.91 & 0.58 & -460 \\
Control/High & 4.07 & 6.69 & 0.14 \\
\hline
\end{tabular}




\section{Seabird influence and distribution of chenopod shrubs}

The high density of colonial seabirds induces profound changes in the vegetation. The destruction of native perennial vegetation and its replacement by colonizer (weed) species with shorter life cycles has been documented worldwide (Gillham 1956, 1960, Sobey and Kenworthy 1979, Hogg and Morton 1983, Bukacinski et al. 1994, Vidal et al. 1998, 2000). In some cases, the direct physical effects caused by seagulls are the main cause of the destruction of vegetation (Sobey and Kenworthy 1979), while in other cases (in arid or semi-arid conditions) the indirect chemical effects produced by seabird products hamper plant survival in these extreme habitats, favouring salt-tolerant species (Hutchinson 1950, Gillham 1960, Ornduff 1965).

In the Chafarinas Islands, there is a strong spatial segregation between the two main chenopod shrubs. Salsola is widespread and dominates the bushy vegetation of the islands but is virtually excluded from heavily seabird-affected sites; in contrast, Suaeda vera dominates in areas frequently used by seagulls for nesting and resting. There is no evidence of specific physical actions by seagulls to the detriment of Salsola (Varela and De Juana 1986, M. Igual pers. comm.), relative to Suaeda. Therefore, seagull-induced soil changes may be a major factor in the ecological separation of Salsola and Suaeda.

We have proved that a major environmental gradient, reflected by the first CCA axis, is able to explain a significant proportion of Salsola and Suaeda relative abundance. This main gradient is, in turn, fully explained $(99.8 \%)$ by the ratio between soil soluble potassium and soil extractable calcium. The value of this meaningful soil ratio depends on a variable closely associated to seagull products $\left(\mathrm{K}_{\mathrm{s}}\right)$, and on a soil feature $\left(\mathrm{Ca}_{\mathrm{a}}\right)$ mainly related to soluble and exchangeable $\mathrm{Ca}$ contents and to the presence of gypsum or calcium carbonate (but also affected by seabird- induced changes as in $\mathrm{pH}$, soluble $\mathrm{Ca}$ and cation exchangeable capacity).

\section{Leaf nutrient status}

The leaf composition of the three chenopod species is affected to a different extent by the seagull-induced changes in soil. There are some common patterns: 1) the changes in leaf composition which are positively correlated to the SEABIRD variable are also highly correlated to an increased concentration of $\mathrm{K}$ in the soil solution $\left.\left(\mathrm{K}_{\mathrm{s}}\right) ; 2\right)$ the apparently major role of soil calcium availability (relative to $\mathrm{K}, \mathrm{P}$ and $\mathrm{Zn}$ levels) in explaining species distribution and leaf composition is probably related to its well-known counteraction of negative effects of increased salinity, extreme ion imbalances, and excessive $\mathrm{P}$ availability (Grattan and Grieve 1992, Marschner 1995), here induced by seabird products. Together with this "protecting effect", the lower P availability in calcium-rich soils limits Suaeda expansion. Therefore, Ca concentration and some $\mathrm{Ca}$ ratios in leaves are good predictors of both Salsola $(\mathrm{Ca})$ and Suaeda $(\mathrm{Ca} / \mathrm{P})$ abundances, although with opposite effects; and 3) the concentrations of certain micronutrients in leaves are good predictors for the abundance of Salsola $(\mathrm{Zn})$, and for the only trend in Suaeda composition related to seabird presence ( $\mathrm{Fe}, \mathrm{Zn}$ and $\mathrm{Mn})$. Moreover, leaf $\mathrm{Zn}$ (and $\mathrm{Mn}$, as a predictor) levels are significantly related to the seabird signature $\left(\delta^{15} \mathrm{~N}\right)$ in Salsola leaves, confirming the relationship between seabird influence and micronutrient levels in shrub leaves.

Given that leaf composition is significantly linked to soil changes induced by seagull products, and that both leaf and soil composition independently explain the observed changes in Salsola abundance we suggest that the decline of Salsola along the seagull-influence gradient is due mainly to its sensitivity to salinity and to highly unbalanced soil solutions, resulting from the excessive (relative) availability of some nutrients, such as $\mathrm{K}, \mathrm{P}$ and $\mathrm{Zn}$.

It is well known that the excess of soluble $\mathrm{K}$ in soil may interfere with the uptake and physiological availability of $\mathrm{Ca}$ and $\mathrm{Mg}$ (with slower transport rates), and hence may explain their depletion in leaves (Mengel and Kirkby 1982, Marschner 1995). However, in a soil with high availability of $\mathrm{Ca}$, plants are able to preserve the integrity of root cell membranes and the selectivity of ionic transport, thereby minimizing the deleterious effects of high nutrient imbalances in non-tolerant plants (Grattan and Grieve 1992).

The excess of soil $\mathrm{P}$ availability produces $\mathrm{P}$ accumulation in plants, which may be toxic and cause growth reduction; however, soil $\mathrm{Ca}$ reduces $\mathrm{P}$ solubility and counteracts its possible negative effect (Marschner 1995, Ström 1997).

The excess of $\mathrm{Zn}$ in seagull-affected soils may produce toxicity and/or micronutrient imbalance in Salsola plants, which could be adapted to the low $\mathrm{Zn}$ conditions usually prevailing in dry calcareous soils. In fact, Salsola leaf-Zn contents in control sites are in the range considered deficient for most of plants $(<$ 15-20 ppm, Kabata-Pendias and Pendias, 1992), and are consistently lower than in the other two species. $\mathrm{Ca}$ competes with $\mathrm{Zn}$ for chelating agents in the soil, and the $\mathrm{Zn} / \mathrm{Ca}$ ratio may well indicate the level of $\mathrm{Zn}$ interference in absorption of other micronutrients or in toxicity (Marschner 1995). 


\section{Nutrient concentration in leaves and species performance}

Salsola seems to have a low capacity of regulation of nutrient inputs, and a tendency to accumulate key nutrients when availability increases. It is well documented that "luxury consumption" allows the plant to accumulate scarce soil nutrients during pulses of higher availability (e.g. during the wet season or sporadic nutrient supply) to maintain growth. However, if the availability of critical nutrients is drastically and continuously increased, there is a risk of accumulating excess of the formerly limiting nutrients (e.g. P or $\mathrm{Zn}$ ) up to toxic levels, and of having unbalanced uptake of nutrients with deficient nutritional status and reduced growth (Chapin 1988, Marschner 1995, Grundon et al. 1997). Hyperfertilization and salinization, induced by seabird products, could have mitigated some of the previously existing main causes of resource stress, and introduced new ones. These changes in soil conditions and source of stress may have favoured a replacement of plants more tolerant to nutrient and water shortage (such as Salsola) by others with greater physiological capacity of ionic regulation and better adapted to cope with saline stress (such as Suaeda).

We have found two apparently contrasting "stresstolerance" behaviours: first, a relative "nutrient- and drought-stress tolerance", but guano sensitive, represented by Salsola, and second, a more "halophytic" one, represented by Suaeda, able to tolerate salinity and highly unbalanced soil solutions, and to regulate nutrient input according to growth possibilities, thus avoiding nutrient accumulation. The latter behaviour requires higher nutrient and water availability, and would thus be favoured by seabird nutrient subsidies, but it would hardly resist $\mathrm{P}$ and micronutrient shortage in non-fertilized (seabird-free), dry, calcareous soils.

Results of ${ }^{13} \mathrm{C}$ isotopic analysis of Suaeda and Salsola leaves are consistent with the hereabove statement: Salsola shows typical $\delta^{13} \mathrm{C}$ values of $\mathrm{C}_{4}$ species $\left(-14.5\right.$ to $-11.5 \%$ ) whereas Suaeda $\delta^{13} \mathrm{C}$ values (25.7 to $-21.8 \%$ ) are typical of $\mathrm{C}_{3}$ species (Winter 1981; Akhani et al. 1997). Present phytogeographical patterns in the Chenopodiaceae clearly show that the $\mathrm{C}_{4}$ pathway confers advantage in arid regions, with or without salinity, especially for perennial life-forms, while the $\mathrm{C}_{3}$ pathway apparently confers advantage on widespread annual and perennial hygrohalophytes such as Suaeda vera (Akhani et al. 1997).

\section{Differential tolerance to seabird-induced soil changes}

The observed small niche overlap between the two dominant shrubs, Salsola and Suaeda, along the seabird influence gradient may be have two main causes: (i) the two species have different ranges of tolerance to the seabird-induced soil changes, or (ii) the small overlap is an outcome of competition for a shared essential limiting resource, e.g. water. Most probably, both causes are operating to produce the observed substantial niche segregation. Our results, linking seabird influence to changes in soil properties, species relative abundance, and leaf composition, favour the hypothesis of a segregation of the species along the seabird influence gradient related to the lower tolerance of Salsola to nutrient imbalances and soluble salts excess, and to the amelioration of conditions for Suaeda establishment (by fertilization and mitigation of micronutrient and water stress).

We have found in Salsola a strong negative correlation between seabird signature $\left(\delta^{15} \mathrm{~N}\right)$ and a variable $\left(\delta^{13} \mathrm{C}\right)$ associated to a physiological trait $\left(\mathrm{C}_{4}\right.$ pathway) giving higher water-use efficiency (WUE). The $\delta^{13} \mathrm{C}$ decrease is significantly related to the main predictor of Salsola presence and abundance $\left(\mathrm{K}_{\mathrm{s}} / \mathrm{Ca}_{\mathrm{a}}\right.$ ratio, or CCA axis 1), to the secondary independent tendency in its leaf composition and to the SEABIRD variable. All these relationships could be interpreted as an interference by the seabird-derived products in this major adaptive trait. The soil-leaf- $\delta^{13} \mathrm{C}$ relationships point to some negative effect of the excess of nitrate and/or soluble $\mathrm{K}$ in the soil solution, and of the increased in leaf $\mathrm{N}$ and $\mathrm{Fe}$, on processes responsible for increasing Salsola $\delta^{13} \mathrm{C}$ leaf values. In contrast, soil $\mathrm{Na}$ and $\mathrm{Mg}$, and the secondary leaf PCA axis (positively correlated with leaf $\mathrm{Na}$ and $\mathrm{Mg}$ ), are all positively related to $\delta^{13} \mathrm{C}$ values. It is known that suitable levels of both $\mathrm{Na}$ (an essential nutrient for $\mathrm{C}_{4}$ species) and $\mathrm{Mg}$ (required for PEP carboxylase function) are needed by $\mathrm{C}_{4}$ plants (Barceló et al. 1987, Marschner 1995). However, both elements are progressively depressed, with respect to K, in Salsola leaves along the seabird influence gradient.

Pyankov et al. (1997) stated that depletions $(<2 \%$ ) in average leaf $\delta^{13} \mathrm{C}$ of $\mathrm{C}_{4}$ species may be interpreted as an indication of a less effective operation of $\mathrm{C}_{4}$ photosynthesis. We suggest that a seabird-induced interference in the $\mathrm{C}_{4}$ pathway, and the consequent reduced $\delta^{13} \mathrm{C}$ levels and related loss of WUE, might contribute to an explanation of the steep decline of Salsola abundance along the seabird-influence gradient.

Acknowledgements - We thank Georgina Álvarez for the organizational support in our fieldtrips to Chafarinas. T. Gómez, M. Igual, J. Charco, and P. Robles gave field assistance. R. López, J.M. Alegre, J. Cara and E. Gutiérrez carried out plant and soil chemical analyses. D. G. Sobey kindly provided some key references. J.M. Murillo and L. Sack made valuable comments on an earlier version of the manuscript. This research was supported by the Spanish Ministry of Environment, and T.M. by the DGES (grant PB97-1177). 


\section{References}

Akhani, H., Trimborn, P. and Ziegler, H. 1997. Photosynthetic pathways in Chenopodiaceae from Africa, Asia and Europe with their ecological, phytogeographical and taxonomical importance. - Pl. Syst. Evol. 206: 187-221.

Anderson, W. B. and Polis, G. A. 1998. Marine subsidies of island communities in the Gulf of California: evidence from stable carbon and nitrogen isotopes. - Oikos 81: 84-90.

Anderson, W. B. and Polis, G. A. 1999. Nutrient fluxes from water to land: seabird affect plant nutrient status on Gulf of California islands. - Oecologia 118: 324-332.

Barceló, J., Nicolás, G., Sabater, B. and Sánchez, R. 1987. Fisiología vegetal. - Pirámide.

Bressler, E., McNeal, B. L. and Carter, D. L. 1982. Saline and sodic soils. Principles-dynamic-modelling. - SpringerVerlag.

Bruce, P., Simon, J. and Oswald, T. 1999. Resampling Stats. User's guide. - Resampling Stats.

Bukacinski, D., Rutkowska, A. and Bukacinska, M. 1994. The effect of nesting black-headed gulls (Larus ridibundus L.) on the soil and vegetation of a Vistula River Island Poland. - Ann. Bot. Fenn. 31: 233-243.

Burger, A. E., Lindeboom, H. J. and Williams, A. J. 1978. The mineral and energy contributions of guano of selected species of birds to the Marion Island terrestrial tcosystem. - S. Afr. J. Antarct. Res. 8: 59-70.

Chapin, F. S. III. 1988. Ecological aspects of plant mineral nutrition. - Adv. Miner. Nutr. 3: 161-191.

Cocks, M. P., Balfour, D. A. and Stock, W. D. 1998. On the uptake of ornithogehic products by plants on the inland mountains of Dronning Maud Land, Antarctica, using stable isotopes. - Polar Biol. 20: 107-111.

Gillham, M. E. 1956. Ecology of the Pembrokeshire Islands. V. Manuring by the colonial sea-birds and mammals, with a note on seed distribution by gulls. - J. Ecol. 44: 429454.

Gillham, M. E. 1960. Destruction of indigenous heath vegetation in Victoria sea-bird colonies. - Aust. J. Bot. 8 $277-317$.

Gillham, M. E. 1961. Alteration of the breeding habitat by sea-birds and seals in Western Australia. - J. Ecol. 49 289-300.

Grattan, S. R. and Grieve, C. M. 1992. Mineral element acquisition and growth response of plants grown in saline environments. - Agric. Ecosyst. Environ. 38: 275-300.

Grundon, N. J., Robson, A. D., Lambert, M. J. and Snowball, K. 1997. Nutrient deficiency and toxicity symptoms. - In Reuter, D. J. and Robinson, J. B. (eds), Plant analysis. An interpretation manual. CSIRO Publishing, pp. 37-50.

Hawke, D. J., Holdaway, R. N., Causer, J. E. and Ogden, S 1999. Soil indicators of pre-european seabird breeding in New Zealand at sites identified by predator deposits. Aust. J. Soil Res. 37: 103-113.

Headley, A. D. 1996. Heavy metal concentrations in peat profiles from the high Arctic. - Sci. Tot. Environ. 177 105-111.

Hogg, E. H. and Morton, J. K. 1983. The effects of nesting gulls on the vegetation and soil of islands in the Great Lakes. - Can. J. Bot. 61: 3240-3254.

Holm, S. 1979. A simple sequential rejective multiple test procedure. - Scand. J. Stat. 6: 65-70.

Hutchinson, G. E. 1950. The biogeochemistry of vertebrate excretion. - Bull. Am. Mus. Nat. Hist. 96: 1-554.

Kabata-Pendias, A. and Pendias, H. 1992. Trace elements in soils and plants. - CRC Press.

Malloch, A. J. C. 1972. Salt-spray deposition on the maritime cliffs of the Lizard Peninsula. - J. Ecol. 60: 103-112.
Marschner, H. 1995. Mineral nutrition of nigher plants, 2nd Edition. - Academic Press.

Martens, D. C. and Lindsay, W. L. 1990. Testing soils for cooper, iron, manganese, and zinc. - In: Westerman, R. L. (ed.), Soil testing and plant analysis. SSSA Book Series, nr 3 , pp 229-264.

Mengel, K. and Kirkby, E. A. 1982. Principles of Plant Nutrition, 3rd edition. - International Potash Institute.

Mizutani, H. and Wada, E. 1988. Nitrogen and carbon isotope rations in seabird rookeries and their ecological implications. - Ecology 69: 340-349.

Mizutani, H., Kabaya, Y., Moors, P. J. and Speir, T. W. 1991. Nitrogen isotope ratios identify deserted seabird colonies. - Auk 108: 960-963.

Moors, P. J., Speir, T. W. and Lyon, G. L. 1988. Soil analyses and ${ }^{12} \mathrm{C} /{ }^{13} \mathrm{C}$ identify sites of deserted rockhopper penguin colonies. - Awk 105: 796-799.

Ornduff, R. 1965. Ornithocoprophilous endemism in Pacific Basin angiosperms. - Ecology 46: 864-867.

Otero, X. L. 1998. Effects of nesting yellow-legged gulls (Larus cachinnans Pallas) on the heavy-metal content of soils in the Cies Islands (Galicia, north-west Spain). - Marine Pollut. Bull. 36: 267-272.

Pyankov, V. I., Voznesenkaya, E. V., Kuz'min, A. N. et al 1997. Occurrence of $C_{3}$ and $C_{4}$ photosynthesis in cotyledons and leaves of Salsola species (Chenopodiaceae). Photosynth. Res. 63: 69-84.

Rieu, M., Vaz, R., Cabrera, F. and Moreno, F. 1998. Modelling the concentration or dillution of saline soil-water systems. - Eur. J. Soil Sci. 49: 53-63.

Slobodchikoff, C. N. and Schulz, W. C. 1980. Measures of niche overlap. - Ecology 61: 1051-1055.

Smith, V. R. 1978. Animal-plant-soil nutrient relationships on Marion Island (Subantarctic). - Oecologia 32: 239-253.

Smith, V. R. 1979. The influence of seabird manuring on the phosphorous status of Marion Island (Subantarctic) soils. - Oecologia 41: 123-126.

Sobey, D. G. and Kenworthy, J. B. 1979. The relationship between herring gulls and the vegetation of their breeding colonies. - J. Ecol. 67: 469-496.

Srivastava, O. P. and Sethi, B. C. 1981. Contribution of farm yard manure on the build up of available zinc in an aridisol. - Commun. Soil Sci. Plant Anal. 12: 355-361.

Stapp, P., Polis, G. A. and Sánchez, F. 1999. Stable isotopes reveal strong marine and El Niño effects on island food webs. - Nature 401: 467-469.

Ström, L. 1997. Root exudation of organic acids: importance to nutrient availability and the calcifuge and calcicole behaviour of plants. - Oikos 80: 459-466.

Tatur, A., Myrcha, A. and Niegodzisz, J. 1997. Formation of abandoned penguin rookery ecosystems in the maritime Antarctic. - Polar Biol. 17: 405-417.

Varela, J.M. and De Juana, E. 1986. The Larus cachinnans michaelis colony of Chafarinas Islands. - In: Medmaravis and Mombailliu (eds), Mediterranean marine avifauna. Springer-Verlag, pp. 231-234.

Vidal, E., Medail, F., Tatoni, T. and Vidal, P. 1998. Impact of gull colonies on the flora of the Riou Archipelago (Mediterranean Islands of SE France). - Biol. Conserv. 84: $235-243$

Vidal, E., Medail, F., Tatoni, T. and Bonnet, V. 2000. Seabirds drive plant species turnover on small Mediterranean islands at the expense of native taxa. - Oecologia 122: $427-434$

Wild, A. 1988. Russell's soil conditions and plant growth, 11th edition. - Longman.

Winter, K. 1981. C $_{4}$ plants of high biomass in arid regions of Asia. Occurrence of $\mathrm{C}_{4}$ photosynthesis in Chenopodiaceae and Polygonaceae from the Middle East and USSR. Oecologia 48: 100-106. 